\title{
The bicameral system as a successor to decentralisation
}

UDK: $342.25(045)$

\author{
Miloš Senčur \\ University of Ljubljana, Faculty of Administration, Slovenia \\ milos.sencur@fu.uni-lj.si
}

\begin{abstract}
The present paper focuses on the issue of territorial principle in a bicameral system which has remained until today the prevailing element in the development of the second chamber of parliament. By presenting its role in the Slovenian and comparable legal systems, the paper suggests that the territorial second chamber of parliament is ever more becoming an indispensable condition also for unitary states with a high level of decentralisation, blurring the distinction between unitary and federal states in such respect. The differences in the role and position of the second chamber are mainly related to the level of decentralisation or development of the local government and, occasionally, to the form of state power. In fact, the weakening of the parliament's role in relation to the executive also diminishes the role and position of the second chamber. Nevertheless, the significance of bicameral decisionmaking in theory and in practice remains unchanged.
\end{abstract}

Key words: parliament, decentralisation, bicameral system

JEL: $K 19$

\section{Introduction}

An important element in the development of a bicameral representative body - particularly in the light of the findings and experience from comparable legal systems and the tradition or experience of the country concerned - is the form of state organisation to which territorial representation is closely related. In the countries governed by a federal system, a bicameral parliament is the 


\section{Miloš Senčur}

\section{The bicameral system as a successor to decentralisation}

conditio sine qua non for the implementation of the federal principle which also implies proper representation of territorial units in the federal parliament. Thus, what needs to be examined is to what extent internal subdivision affects the establishment of the bicameral system based on the territorial principle in the case of unitary states, and what is then the role of the second chamber. In both cases, the latter should act as a specific mechanism of breaks and balances in the functioning of the (central) legislature.

A characteristic of both federal and unitary states is that power is not necessarily centralised - based on the principle of vertical subsidiarity, numerous tasks are transferred into implementation or even management of various forms of territorial organisation whose relations with the central government are based, in the relevant circumstances, mainly on cooperation and interdependence. Practically any state has, in addition to the central level, also a lower level of government represented by a more or less developed and diversified local government. This is known as territorial decentralisation.

The number of levels between the central and local governments depends on the individual country, ${ }^{\mathbf{1}}$ mainly on its size, on historical developments, and increasingly often on the requirements brought about by the contemporary management process. ${ }^{2}$ As regards the various forms and levels of territorial organisation, a process of integration is in place aimed at gathering the various elements of the social system under a common framework, as appropriate. This by itself points to varying dimensions of the relations between central government and territorial units, particularly their interactions.

\section{Forms of territorial decentralisation}

The shaping of sub-national authorities is a continuous search for the right balance between decentralisation and centralisation, and thereby a search for new forms of organisation, also on territorial basis. A significant criterion in the

1 Brezovšek states that the existence of a network of territorial units is a prerequisite of the modern state (Brezovšek, 1997, p. 188). According to DEXIE, Paris (publication EU Subnational governments: an overview) EU Member States comprise 92,500 sub-national communities or authorities (Vlaj, 2009).

$\mathbf{2}$ If there is only one level of local government, conflicts and polarity arise in the relations between the state and the local communities. On the other hand, an excessive number of levels normally presents negative consequences for the management process in terms of its efficiency. 
selection of decentralisation measures of structural, financial and other nature should be, in particular, the tendency to reasonably eliminate any territorial drawbacks or strive for the equality of living conditions of the population at the level of a broader state community. ${ }^{3}$

In practice, various forms and methods for a top-down transfer of state's tasks exist. ${ }^{4}$ They refer either to the least intense level of transfer - i.e. deconcentration or administrative decentralisation $\mathbf{5}^{\mathbf{5}}$ where the performance of authoritative and other tasks is entrusted with bodies outside the central location, mainly owing to functional and organisational needs of the central administrative organisation and population's needs for access to administrative services or to decentralisation in a stricter sense where transfer also implies the right to formulate policies and, partly, self-control over the implementation of the tasks. ${ }^{6}$

One of the forms and consequences of decentralisation in the management of public affairs is local government. The powers of local government are provided by the constitution ${ }^{\mathbf{7}}$ which also sets the boundaries of its operation and control. Local government is an important method of societal (self)regulation ${ }^{\boldsymbol{8}}$ and at the same time an indivisible part of state organisation. ${ }^{\boldsymbol{9}}$ For such reason, the relations between local communities and the state are considered an essential element of self-governance. Based on the principle of vertical separation of power, this involves reciprocal control in the relations with the state and the possibility of local community representation at the cen-

3 Establishing the right balance in the distribution of public revenue between central government and territorial units to finance their public needs is a problem and hardly resolvable issue also in Slovenia. More about the significance of the economic aspect of decentralisation in Bugarič, 1998, p. 121-130.

4 Over the last one hundred years, a characteristic of the territorial units in Slovenia is that the management of public affairs has been organised at several territorial levels where local and state tasks intertwine. Eventually, a single-level public utility system was established as an attempt to design the optimal self-governance and authority community in terms of achieving balance between the frequency of administrative tasks and the number of population and size of the territory.

5 The term is, for example, explicitly used in Article 5 of the Italian constitution regulating the services depending on the state (see: http://www.senato.it/istituzione/29375/ articolato.htm, accessed on 2 October 2009).

$\mathbf{6}$ In such case, theory speaks of political decentralisation as the highest level of autonomy (Porta, 2003, p. 207).

7 Cf. draft Constitution of the Republic of Slovenia, Poročevalec - bulletin of the Assembly of the Republic of Slovenia, No. 17/90, p. 20.

$\mathbf{8}$ Thus, the same territory is managed by two governments, whereby also the state must subject to the local government (e.g. in spatial planning).

9 For example, the state gives local communities guidelines for spatial planning although such issue falls in the scope of work of the local government. 
Miloš Senčur

The bicameral system as a successor to decentralisation

tral level. It is also the basis to determine the scope of influence of local communities on the regulation of their position and relations with the central authority. The higher the level of decentralisation (in political and economic terms), the more attention is devoted to issues relating to the separation of power between the state's centre and its parts, and those relating to the impact the latter should have on the shaping of central bodies and the decisions they make. The level of decentralisation is also directly proportional to the need for adequate interconnection between the system and its parts, which often results in the form of a bicameral structure of the central authority.

However, the bicameral system is not the only form of separation of state powers, and the principle of horizontal separation of power is not the only aspect of bicameralism. In fact, political or social power is not distributed just horizontally in the classical sense, but also vertically. The principle of the vertical separation of power is indeed gaining importance since a considerable share of power should be held by the local government. ${ }^{10}$ The holders of such power have, given their self-governing position, at the same time the right to present their views and participate in the resolution of issues relating to the exercise of local government. ${ }^{11}$

\section{Conceptual bases and practices of territorial representation in comparable countries}

The oldest - and in a certain sense considered as reference - second chamber is the United States Senate, ${ }^{\mathbf{1 2}}$ established as early as 1787 . Contrary to most other chambers the Senate has, to date, undergone no significant changes in terms of equality with the Congress' House of Representatives. Originally, the Senate had been designed as representative of the federal units although here, too, the interests of political parties later (mainly following the

10 Cf. Decision of the Constitutional Court of the Republic of Slovenia No. U-I-176/04 (Official Gazette of the Republic of Slovenia No. 21/06).

11 Cf. Decision of the Constitutional Court of the Republic of Slovenia No. U-I-24/07 (Official Gazette of the Republic of Slovenia No. 101/07).

$12 \mathrm{~A}$ model to numerous federations. For example, at the Melbourne conference of 1890 the delegates from all Australian colonies decided for a future federal organisation of the country with a bicameral central parliament (more at: http://parlinfo.aph.gov.au/parllnfo/, accessed on 2 October 2009). 
introduction of direct elections) prevailed over the interests of individual states. $^{13}$

The U.S. model was followed by the Swiss constitution of 1848 introducing a bicameral federal legislature. ${ }^{\mathbf{1 4}}$ According to the existing constitutional system (constitution of 1999), the Federal Assembly is composed by the National Council and the Council of States. The power and freedom of the Swiss cantons has reflected in the role and position of the second chamber, except during the relatively short existence of a unitary state. In terms of powers, the second chamber has been equal to the first and the cantons have been allowed to autonomously define the manner in which it would be structured. ${ }^{\mathbf{1 5}}$ The importance of the upper chamber diminishes in the event of joint sessions where the numerical advantage of the first chamber comes to the fore. Its role as protector of the cantons' interests is further reduced in the event of a referendum where such role is entrusted to the people. Nevertheless, over the last decades Switzerland has been characterised by centralisation affecting its transformation into a group of unitary states. ${ }^{\mathbf{1 6}}$

Germany introduced a federal type of government with the constitution of 1871 although the legislative power was mainly in the hands of the central authority, weakening the role and position of the federal units. ${ }^{\mathbf{1 7}}$ Later on, the Weimar constitution restricted also the powers of the second chamber, and the prevailing opinion today is that Germany was then close to a decentralised unitary state. ${ }^{\mathbf{1 8}}$ Following the rise of Hitler to power, the second chamber and the Länder were abolished in $1934 .{ }^{\mathbf{1 9}}$ In the post-war period, both German states had bicameral parliaments and both upper chambers were representatives of territorial units. ${ }^{\mathbf{2 0}}$ With the German reunification in 1990, the constitution of West Germany prevailed. The Federal Council (Bundesrat) is subordinate to the first cham-

13 Grad et al., 2004, p. 143.

14 Brlić, 1931, p. 467.

15 In the past the representatives of the states were occasionally elected by the states' assemblies; today, they are elected directly. The cantons' regulations also provide for a uniform duration of their term of office (data from: http://www.ipu.org/english/home.htm, accessed on 2 October 2009).

16 Trifunovska, 1991, p. 138. On the other hand, there are signs of decentralisation resulting in the enhanced vertical integration among the cantons and local government units (Zimmermann, 1993, p. 86).

17 The then federal state was often named pseudo-federalism (Beyme, 2002, p. 307).

$18 \mathrm{Grad}$ et al., 2004, p. 91.

$19 \mathrm{lbid}$.

20 The representatives of the second chamber of East Germany were elected by the assemblies of these units, yet their decisions were not binding. The Länder were abolished in 1952 and the country became a unitary state (Grad et al., 2004, p. 108). 


\section{Miloš Senčur}

\section{The bicameral system as a successor to decentralisation}

ber. $^{\mathbf{2 1}}$ It has the right to absolute veto on certain laws, ${ }^{\mathbf{2 2}}$ and to suspensive veto on all other legislation. ${ }^{\mathbf{2 3}}$ The members of the Federal Council are elected by the state governments from among their members ${ }^{\mathbf{2 4}}$ and have an imperative term meaning that they must follow the instructions of their state governments. ${ }^{\mathbf{2 5}}$

The 1920 constitution of Austria, pursuant to which the second chamber reflected the federal organisation of the state, was amended twice (in 1925 and 1929), whereby the 1929 amendment expanded the second chamber to also include professions. ${ }^{\mathbf{2 6}}$ Such change to the structure of the second chamber was radically upgraded with the new constitution of 1934 when the second chamber completely lost its role of representative of territorial units. The constitutional act of 1945 re-established the original constitution and returned to the second chamber powers similar to those originally provided. In such context, in addition to the right to legislative initiative and suspensive veto, mention needs to be made of the right to consensus to the decisions of the first chamber in specific cases. ${ }^{27}$

The Spanish autonomous communities are sometimes compared with the German Länder, ranking Spain among highly decentralised and almost federal

21 According to von Beyme, the Bundesrat is not a second chamber. It has a rather semiparliamentarian character shown by the fact that the public takes no interest in its work, that its members vote unitarily as a delegation, that control over the government is indirect, etc. (Beyme, 2002, p. 310). At some point the author concludes that the Bundesrat has - contrary to the expectations of the authors of the constitution - developed into a strong second chamber (p. 316), which is of course closer to the actual situation (Russell, 2000, p. 216-218). 22 This is useful mainly in the event of amendments to the constitution, laws affecting public finance, and those affecting the states' administrative jurisdiction (more at: http://www.bundestag.de, accessed on 2 October 2009).

23 Pursuant to Article 50 of the German constitution, the Länder participate through the Bundesrat in the legislation and administration of the Federation and in matters concerning the European Union (see: http://www.bundestag.de/gesetze/gg/, accessed on 2 October 2009).

24 From three to six representatives, depending on the number of inhabitants in the individual federal state. The term of office of the members of the Bundesrat is not fixed - they are appointed and removed by the state governments (data retrieved from: http://www.ipu.org/english/home.htm, accessed on 2 October 2009).

25 According to theoreticians, the Bundesrat is a unique and most successful second chamber in terms of territorial representation. It has no party groups and the positions of its members often influence the parties' policies. The second chamber provides a mechanism of control over federal legislation, while its potential force to block such legislation creates a system of interconnection and mutual influence between the federation and the states (Russell, 2001b, p. 114 and 115).

26 The amendment was a result of the requests for true democracy made by political parties (Polzer-Srienz, 2000, p. 27).

27 Theory described such status of the second chamber as a false bicameral system, where the already insignificant representation of federal units' interests at the federal level is increasing with the predominance of party interests (Koja, 1970, p. 259). 


\section{The bicameral system as a successor to decentralisation}

countries. $^{\mathbf{2 8}}$ In the Spanish Senate, most members are directly elected within territorial units while other members are elected by their representative bodies. For such reason the Senate is often regarded as an unusual second chamber where directly elected members have no natural links with the local authorities although they are mostly also members of autonomous communities' legislatures. $^{29}$

Likewise, most of the many constitutional systems of France considered territorial representation to be an essential part of any parliament. During the Third Republic, the Senate represented the communes as the oldest and most important social groups, and the two chambers had, in principle, equal powers in the legislative procedure. ${ }^{\mathbf{3 0}}$ The Fourth Republic significantly restricted the powers of the second chamber, while the 1958 constitution of the Fifth Republic (still applicable today) provides that territorial units must be represented in parliament. ${ }^{\mathbf{3 1}}$ According to theoreticians, the involvement of local interests at the state level implies a similar representation as the one established in federally and regionally organised countries, giving the local authorities great possibilities to influence decisions at higher levels (the Senate is actually the council of the French communes). ${ }^{32}$

The Italian Senate is constitutionally shaped on a regional basis. ${ }^{\mathbf{3 3}}$ It would therefore be expected that it mainly acts as representative of the regions yet such role of the Senate and the importance of the regions in the system of bicameralism are diminished through the influence of political parties. ${ }^{\mathbf{3 4}}$ One of the proposals to reform the constitutional system in Italy was for the Senate to have less members elected by representatives of municipal, provincial and regional councils, while general legislative power would be held exclusively by the lower house. ${ }^{\mathbf{3 5}}$

28 Šmidovnik, 1993, p. 203.

29 Russell, 2001b, p. 211.

$30 \mathrm{~A}$ similar system of election to Senate applied in Sweden where the members of the upper house were elected by representative bodies of the provinces and the delegates of the cities that were not represented in provincial representative bodies (Stefanović, 1931, p. 540).

31 Cf. Article 24 of the constitution (http://www.assemblee-nationale.fr/connaissance/ constitution.asp, accessed on 2 October 2009).

32 Meny, 1998, p. 117.

33 The Italian system recognises four levels of authority. The regions may autonomously adopt laws related to several areas and also hold legislative initiative (http://www.senato.it/istituzione/29375/articolato.htm, accessed on 2 October 2009).

34 As a rule, the representatives of both chambers gather in parliamentary groups by party affiliation (Osnove, 1998, p. 70).

35 Klarić, 2005, p. 177 and 178. 


\section{Miloš Senčur}

\section{The bicameral system as a successor to decentralisation}

As seen above, the prevailing and most common method for the development of the second chamber of parliament today is regional basis ${ }^{\mathbf{3 6}}$, serving as a model for the modern state. ${ }^{\mathbf{3 7}}$ In federal countries, the reasons for a bicameral system are practically the same and consider bicameralism a necessary consequence of such type of state organisation. With some rare exceptions, all federations have bicameral parliaments, ${ }^{\mathbf{3 8}}$ the second chamber acting as representative of the federal units. ${ }^{\mathbf{3 9}}$ In unitary countries, the structure of parliament mainly depends on the level of the country's decentralisation and development of its local government. The importance of territorial representation varies.

In the countries governed by bicameral systems where territorial representation plays an important role, significant differences are observed in the role and position of the second chamber owing to different historical development and social changes in individual countries, ${ }^{40}$ particularly in economics and politics (e.g. creation of political parties and strengthening of their role), ${ }^{\mathbf{4 1}}$

36 Territorial representation is in fact the prime component of the modern bicameral parliament, and also the English model of bicameralism originally derived from the territorial principle.

37 E.g. in late March 2009, Ukraine submitted into parliamentary procedure a new draft constitution providing for the introduction of a bicameral parliament. The Ukrainian president chose such option based on the example of other countries with established bicameral systems. The parliament would thus gather representatives of political forces in the lower house, elected directly according to a proportional system, and representatives of local communities (regions), entering the upper house directly based on a majority electoral system under the principle of parity (Juščenko, 2009, p. 5). Similarly, the Serbian constitutional law theory states that regionalisation of the country would also reflect in the structure of parliament, although unicameral (Pejić, 2005, p. 80).

38 E.g. Saint Kitts \& Nevis, Micronesia and Venezuela (Massicote, 2001, p. 152)

39 The bicameral system is sometimes characteristic also of the federal units. Australia for example only has one exception - Queensland, where the second chamber was abolished already in 1922. More in Abolition of the Upper House, Information on Parliament and Government in Queensland, p. 1-11 (website: http://www.parliament.qld.gov.au./, accessed on 2 October 2009), stating that a unicameral parliament is a deviation from democracy while a bicameral system is what every governance needs. Such statement is understandable since bicameral parliaments based on the English model persisted in the Australian federal units even in the time of the colonies status, mostly for the same reasons as those typical of unitary states, i.e. for serving as brake and balance of the legislature.

40 A typical example is France where in the 200 years of history of bicameral parliament (or even multicameral in a certain period of time) its second chamber experienced several transformations both in terms of composition and powers. Quite similar was the situation in former federal Yugoslavia where social changes explicitly reflected in the organisational changes of representative bodies at all levels of power.

41 For example, the US Senate in its role of representative of the interests of the ownership structures of financial, commercial and large estates nature has often supported regulations strengthening the power of the federation on the account of the states; therefore, today's discussions about its role and the need for its further existence are similar as in unitary countries with bicameral systems (Hague et al., 2001, p. 275). Already Laski believed that the 


\section{The bicameral system as a successor to decentralisation}

distinctions in terms of equality of territorial units, ${ }^{\mathbf{4 2}}$ varying possibilities of territorial units' participation in and influence on decision-making at the central level, ${ }^{\mathbf{4 3}}$ federalisation processes, ${ }^{\mathbf{4 4}}$ centralisation and decentralisation over different periods, ${ }^{\mathbf{4 5}}$ new patterns of public affairs management, etc.

On the other hand, these countries have numerous points in common which are rooted, among other, in the form of their state organisation or state authority. The prevailing conviction is that the second chamber in the legislatures of federal countries has a more important role than the second chamber in unitary countries. This is, given the grounds for its existence, a justified supposition although not sufficiently confirmed by practice. Obviously, the form of state organisation is important ${ }^{\mathbf{4 6}}$ and to some extent affects the role and position of the second chamber. ${ }^{47}$

It may well be said that where the parliament as a system is losing importance or where the separation of power is less consistent, also the role of the

principle of representation of territorial units in the U.S. Senate was outwitted by the activity of the party system since the republicans in the Senate and those in the House of Representatives always vote the same (Laski, 1934-35, p. 60).

42 As a rule, all territorial units in the second chamber of the federal parliament have the same number of representatives irrespective of the unit's size and population (Pejić, 2005, p. 78). Yet since the role of the territorial element is in practice disguised by party politics and party loyalty, theoreticians (Russell, 2003, p. 313) believe that it is more important for the dynamics of the second chamber that no political party has excessive majority in the second chamber than that all territorial units are represented therein on a parity basis.

43 In some federal countries, these possibilities are not available merely within the framework of activities of the second chamber but also in other ways (e.g. the decisions of the federal parliament must be approved by a certain number of federal units or their parliaments, such as in Switzerland, Canada, and similarly in former Yugoslavia). Pursuant to the constitution of 1793, the French unicameral parliament had to forward the adopted laws to all communes in the country to obtain their opinion (if a tenth of the communes from most departments opposed a law, the parliament had to convene what was known as primary assemblies for the law to be finally adopted). Thus, the territorial communities of France had a role similar to those in bicameral systems. On the other hand, there are cases such as the Canadian parliament where members of the Senate are appointed by the federal government, thus questioning the role of the second chamber as representative of federal units.

44 Belgium was a unitary and centralised state for a long time, but since 1970 gradually pursued decentralisation and federalism to officially become a federal country in 1993 (Lijphart, 1999, p. 100). Belgium is an example showing that the boundaries between federal in regional assembly may also be blurred (Ribičič, 2000, p. 56).

45 This is a constant process of redistribution of tasks between the central government and the territorial units in order to strengthen the one or the others.

46 Canada, Germany and Austria are characterised by a subordinate role of the second chamber although these countries have a federal system, yet have at the same time a parliamentary form of power (a partial exception in this group of countries is Australia, but also there the second chamber has a minor role when it comes to relations with the government or adoption of finance-related laws ).

47 In federal countries with an assembly system (e.g., Switzerland and the former socialist countries), with a presidential system (e.g. USA), or with prevailing elements of the presidential system (e.g. Russia), the role of the second chamber in parliament is more equal. 
Miloš Senčur

The bicameral system as a successor to decentralisation

second chamber is diminishing. ${ }^{\mathbf{4 8}}$ A specific example in such regard is the Italian system: Italy is a unitary country and a parliamentary republic, and nevertheless the Senate and the Chamber of Deputies are fully equal. Yet the Italian case presents several important circumstances which somewhat explain this peculiarity. For example, the president - although indirectly elected - has a greater role and a stronger position than in other parliamentary systems, including Slovenia. ${ }^{\mathbf{4 9}}$ Moreover, despite its unitary organisation, Italy features a strong regional component ${ }^{\mathbf{5 0}}$ also reflected in the frequent requests for federalisation.

\section{Territorial representation in the development of Slovenian bicameralism}

Slovenians and the rest of Europe alike have been experiencing different structures and forms of representative bodies over different periods of time and through various systems of state organisation. The bicameral structure of parliament found many advocates even in older theories. ${ }^{\mathbf{5 1}}$ In practice, however, the decisions were the result of the distribution of power among various social groups. Particularly in the case of former Yugoslavia, the dynamics of social relations clearly reflected in numerous changes in the structure of the federal and republic representative bodies. ${ }^{\mathbf{5 2}}$ The fil rouge of such changes was also a series of debates on the importance of territorial representation in the

48 An argument in favour of bicameralism is that the various interests represented in the second chamber are less influenced by the government than in the lower house (Russell, 2001a, p. 442).

49 Longer term of office of the president, the right to form the government, the appointment of senior state officials, the approval of draft laws submitted by the government to the parliament, convening extraordinary sessions of any parliamentary chamber, the right to dismiss them, supervision over the implementation of the legislative function in the form of suspensive veto, are all characteristics testifying to the relatively strong role of the Italian president.

50 The regions have legislative powers in certain areas, the right to legislative initiative, they may request the calling of an abrogating popular referendum; in addition, based on the subsidiarity principle, the central government transferred a series of administrative tasks onto regional governments, provinces and municipalities (Klarić, 2005, p. 174 and 175).

51 Vošnjak, 1920, p. 198-203 in Steska, 1920, p. 1-20. Vošnjak believed that the upper house should represent all socio-economic players in the country, while Steska argued that the participation of territorial autonomous representations in legislation acted as counterbalance to overhasty decisions of the parliament.

52 For a thorough overview of this period see Kristan, 1970, p. 184 and 185. 
legislature. ${ }^{\mathbf{5 3}}$ In Slovenia, the debates about finding the most suitable form of municipal participation in the formulation of republic policies or municipal influence on the work of the republic assembly and on a more consistent implementation of the principle of bicameralism, first resulted in the introduction of the meeting of municipal delegates as a consultative body of the republic assembly, and later on in the establishment of the Chamber of Municipalities as an equal chamber of the Assembly. ${ }^{\mathbf{5 4}}$

The structure of parliament occupied also the thoughts of the authors of the new Slovenian constitution, ${ }^{\mathbf{5 5}}$ particularly in relation to the structure of the future local government. No particular disagreement was expressed in relation to the basic local communities but questions were raised regarding the establishment of broader local communities and their representation at the state level. The opinions thereon were diametrically opposed. Some people believed regions to be unnecessary since the process of regionalisation would at the same time imply a tendency toward the federalisation of the state, while others thought that without establishing the second level the local government could not be developed, which would negatively affect also the promotion of territorial interests in the formulation of state policies. The latter also cautioned that a large number of small and technically weak municipalities and the absence of the second level of local government would lead to an excessive gap in the relation toward the centres of power at the state level. ${ }^{\mathbf{5 6}}$

Over the various stages of drafting the new Slovenian constitution, the National Council as representative of special interests (local, social, professional, etc.) has always been considered an alternative solution in the future structure of parliament, but has not received adequate attention. For such reason, its role and position have been rather undefined ever since its establishment. This applies in particular to the representation of territorial interests which have the absolute majority in the Council. ${ }^{\mathbf{5 7}}$ Thus, the dilemma faced by

53 Session records of the Assembly of the Socialist Republic of Slovenia, No. 38/68, Appendices, p. 472.

54 Already the debates on the draft constitution stressed that in the republic assembly adequate attention should be given to the diversity of municipal interests in all matters which directly affect the interests of the citizens and the position, role and tasks of the municipality as territorial community (Cf. Session records of the Assembly of the Socialist Republic of Slovenia, 61st session of the Chamber of the Republic, 18 July 1973, p. 115).

55 Cf. verbatim records of the debate at the 18th session of the Commission for Constitutional Affairs of the Slovenian Assembly of 12 December 1990.

56 Cf. Ribičič, 2007, p. 331.

$\mathbf{5 7}$ This may be regarded as anachronism since the National Council was established already at the time of "municipal communes". 


\section{Miloš Senčur}

\section{The bicameral system as a successor to decentralisation}

the authors of the constitution about which type of second chamber should be chosen in order to satisfy the tasks of territorial representation and have a positive influence on the legislative activity or social management processes, is still very topical. Also owing to the inconsistent implementation of the principle of vertical separation of power.

The constitutional amendments of 2006 made the two-stage local government compulsory. The intermediate level between the state and the municipalities would be represented by the regions as broader self-governing local communities. This would provide the second chamber of the Slovenian parliament with a more prominent role (either as chamber of the regions or a structurally reformed National Council ${ }^{\mathbf{5 8}}$ ), on condition of a simultaneous consideration of the suitability of its existing powers. Several possibilities are to be examined, from the creation of a strong second chamber, which might even lead to subordination of the first chamber, to the establishment of a second chamber which would in practice qualify as inefficient and unnecessary. The right solution is usually a compromise, which however is only justified if it meets certain criteria (such as powers decisive for the legislative procedure, adequate influence in the relation toward the executive, etc.).

In terms of development, the solutions regarding the future role and position of the National Council should be directed toward:

- a change in the relation between the National Council and the National Assembly as the general representative body, or improved competitiveness of the National Council with adequate redefinition and modification of its powers; and

- a change in its internal structure (partly or entirely), whereby the transformation of the National Council's structure depends on the future development of decentralisation or local government as the territorial aspect thereof.

58 The most interesting, broad, and intense public debate on the possibilities to transform the National Council into a territorial representation or representation of the future regions was held as early as 1998 when both the advantages and disadvantages of possible modifications were presented (see e.g. Grad, 1998, p. 168-172 and Kristan, 1998, p. 173-174); the debate became even more topical following the most recent constitutional amendments (more in Ribičič, 2007, p. 336-339). 


\section{Conclusion}

In most federal countries with bicameral parliaments, the second chamber is established based on the territorial principle. The latter is ever more becoming an indispensable condition also for unitary states with well-developed local government, slowly blurring the differences between them and the federal countries. A contribution to gradual equalisation is made also by political parties whose interests often prevail over the interests of other social groups.

The past experience and the comparisons with other countries provide useful guidelines for future decisions. Some of the existing solutions, an example thereof certainly being the constitutional definition of the National Council, have largely been adopted without due consideration, which results in increasing headache anytime the assessment of the existing and future role or even abolishment of the National Council appears on the political menu.

The interconnection between local and central governments and the need for their cooperation and coordination call for more adequate institutional forms also in Slovenia. Local interests are represented in the National Council, which means that local government is one of the structural elements of the parliament. In addition to political interests mainly pursued by political parties, the parliament should reflect the interests of self-governing territorial units. The National Council thus represents at least a possibility to prevent the absolute monopoly and arbitrariness of the general representative body which may otherwise freely create legislation to fit its own interests or the interests of political elites. Such possibility is, however, only feasible where the second chamber has powers and competences broad enough to make it more equal to the first chamber. This mainly refers to a significant and sometimes even decisive role in the legislative process, in the process of constitutional review, in financial matters, and in the relation toward the executive. If one of the main weapons of the second chamber is suspensive veto whereby it only temporarily suspends the entry into force of a law, then it will hardly meet the expectations - be it a pragmatic promotion of the interests of territorial units or the implementation of democratic standards within the legislative branch. Both cases result in a democratic deficit of public administration, which only differs in terms of its dimension. 


\section{Miloš Senčur}

\section{The bicameral system as a successor to decentralisation}

Miloš Senčur, Senior Lecturer at the Faculty of Administration of the University of Ljubljana, obtained his Bachelor's and Master's Degrees in public administration at the Faculty of Law of Ljubljana. For the last twenty years, he has been engaged in the public sector as member of the first Slovenian parliament, director of municipal administration, head of administrative unit, supreme state auditor for local government, university professor. His hitherto work has been centred on issues such as property law relations among the municipalities, distribution of powers between municipality and the state, elections of representatives of local interests in the National Council, role of municipalities in the legislative procedure, managing the physical assets of the state and municipalities, etc. As an external associate of the ministry responsible for public administration, he has been participating in the programme of compulsory training for appointment in grade for several years.

\section{Sources}

- Beyme, K. (2002). Politični sistem Zvezne republike Nemčije, Koper: Higher Education Centre.

- Brezovšek, M. (1997). Regionalna država med unitarizmom in federalizmom: teoretični modeli teritorialne organizacije oblasti. Teorija in praksa, Year. 34, No. 2/97, p. 183-196.

- Brandt, N. (ur.). (1998). Osnove italijanskega ustavnega prava in Ustava Republike Italije. Ljubljana: Official Gazette of the Republic of Slovenia.

- Brlić, I. (1931). O ustavu i ustavnoj povijesti švicarske konfederacije, Zagreb.

- Bugarič, B. (1998). Ekonomski vidiki regionalizma. V: Ribičič, C. (ur.): Regionalizem v Sloveniji. Proceedings, Official Gazette of the Republic of Slovenia, Ljubljana, p. 121-130.

- Grad, F. (1998). Dvodomnost in zastopanost regionalnih interesov. V: Ribičič, C. (ur.): Regionalizem v Sloveniji. Proceedings, Official Gazette of the Republic of Slovenia, Ljubljana, p. 160-172.

- Grad, F., Kristan, I., Perenič, A. (2004). Primerjalno ustavno pravo. Faculty of Law, Ljubljana.

- Hague, R., Harrop, M. in Breslin, S. (2001). Komparativna vladavina i politika. Uvod. Zagreb.

- Juščenko, V. (2009). Ukrajina potrebuje ustavne spremembe. Delo, 30 April 2009. 


\section{The bicameral system as a successor to decentralisation}

- Klarić, M. (2005). Lokalna samouprava u Italiji prema novom modelu, Zbornik radova Pravnog fakulteta u Splitu, Year 42.

- $\quad$ Koja, F. (1970). Federalizam u Austriji. Arhiv za pravne i društvene nauke, No. 3-4/70.

- Kristan, I. (1970). Dvodomni sistem v Jugoslaviji s posebnim poudarkom na razvoju zbora narodov. Zbornik znanstvenih razprav, Year 34, Ljubljana, p. 179-209.

- Kristan, I. (1998). Državni svet ali Zbor regij? V: Ribičič, C. (ur.): Regionalizem v Sloveniji. Proceedings, Official Gazette of the Republic of Slovenia, Ljubljana, p. 173-185.

- $\quad$ Laski, H. (1934-35). Politička gramatika, Vol. 1 and 2, Beograd.

- Lijphart, A. (1999). Patterns of Democracy, Government Forms and Performance in Thirty-Six Countries. Yale University Press, New Haven in London.

- Massicote, L. (2001). Legislative Unicameralism: A Global Survey and a Few Case Studies. V: Baldwin, N. D. J. in Shell, D. (ur.). Second Chambers, The Journal of Legislative Studies. Vol. 7, Number 1, London.

- Meny, Y. (1998). Francuski politički sustav. Panliber, Osijek-Zagreb-Split.

- Verbatim records of the 18th session of the Commission for Constitutional Affairs of the Assembly of the Republic of Slovenia of 12 December 1990.

- Decision of the Constitutional Court No. U-I-176/04 (Official Gazette of the Republic of Slovenia No. 21/06).

- Decision of the Constitutional Court No. U-I-24/07 (Official Gazette of the Republic of Slovenia No. 101/07).

- Pejić, I. (2005). Dvodomi parlamenti u Evropi: analiza iskustava odabranih zemalja. Evropsko zakonodavstvo, Year IV, No. 14/05, Beograd, p. 75-80.

- Polzer-Srienz, M. (2000). Razvoj ustavnega prava v Avstriji. V: Brandt, N. (ur.): Ustavni sistem Republike Avstrije, Koper: Higher Education Centre.

- Porta, D. D. (2003). Temelji politične znanosti, Ljubljana: Založba Sophia.

- Poročevalec - bulletin of the Assembly of the Republic of Slovenia, No. 17/90.

- Ribičič, C. (2000). Podoba parlamentarnega desetletja, Ljubljana: published by the author.

- Ribičič, C. (2007): Zastopanost pokrajin v slovenskem parlamentu, Javna uprava, Year 43, No. 2/07, p. 331-339. 
Miloš Senčur

\section{The bicameral system as a successor to decentralisation}

- Russell, M. (2000). Reforming the House of Lords, Lessons from Overseas, Oxford University Press, New York.

- Russell, M. (2001a). What are second chambers for?, Parliamentary Affairs, Vol. 54, str. 442.

- Russell, M. (2001b). The Territorial Role of Second Chambers. V: Baldwin, N. D. J. in Shell, D. (ur.). Second Chambers. The Journal of Legislative Studies, Vol. 7, Number 1, London, p. 105-118.

- Russell, M. (2003). Is the House of Lords Already Reformed?, Oxford: The Political Quarterly Publishing Co, p. 311-318.

- Siedentop, L. (2008). Zakaj so ustave pomembne. Official Gazette of the Republic of Slovenia, Revus, Year 1, No. 1/08, p. 110-123.

- Stefanović, J. (1931). Dvodomni sistem u modernim ustavima, Mjesečnik, No. 12/31, p. 534-540.

- Steska, H. (1920). K vprašanju organizacije naše države, Slovenski pravnik, No. 1-4/20, p. $1-20$.

- Šmidovnik, J. (1993). Regionalizem v Evropi in pri nas, Teorija in praksa, Year 30, No. 34/93.

- Trifunovska, S. (1991). Federalne države i medjunarodni ugovori, doctoral thesis, Novi sad.

- Vlaj, S. (2009). Dileme pokrajinizacije Slovenije, lecture of 24 September 2009, Ljubljana: Ifimes-International Institute for Middle East and Balkan Studies.

- Vošnjak, B. (1920). Jedan ili dva doma, Srpski književni glasnik, Nova serija, No. 1/20, p. 198-203.

- Zimmermann, W. (1993). Sistem lokalne samouprave v Švici, Javna uprava, Year 29, No. 1-2/93, p. 81-88. 